\title{
DESCRIPTION OF A HUMAN BEING AT THE UNSTABLE TIME (ON THE SYNERGY ATTEMPT TO LANGUAGE)
}

\author{
NATALIA PUSHKAREVA \\ Saint Petersburg State University, Russia \\ pushkarevanata@gmail.com
}

\section{ABSTRACT}

Time of historical changes in a country is being reflected in the language and provides great influence on the methods of world description. Loosing of traditional connections in the society is being continued in the growing instability and indefiniteness in the language. The expression of indefiniteness used to describe the picture of the world at the time of changes is analysed here. Ways applied to describe a person provide a bright example of mentioned language situation. The same methods appear at totally different fields of language activity such as literal language and spoken language of certain marginal social groups. Descriptions of human beings like objects and of objects like creatures in prose and criminal argot are studied like examples in this article. Destruction of descriptive tradition creates new ways to show impressions of unstable world and activates the potential of language units. Writers with great sense of language sometimes are able to foreseen the future tendencies appearing in such epoch of instability. Analysis of these cases from the synergy position helps to enlarge the knowledge of language process and to trace the link between linguistic and natural process.

KEYWORDS: indefiniteness, description of a person, human being, lifeless object, picture of the world, synergy attempt

Current situation in a language is directly connected to the historical epoch of usage. Comparatively stable epochs in the life of a society is being followed with cardinal changes which have such reflections in a language like disappearance of some words from everyday usage, creation or borrowing of new words, various changes in connotations and stylistic characteristics, appearing of new ways of text organization. At the same time many deviations from the traditional stylistic norms take part in language practice, series of stylistically divided synonyms appear. Language units and constructions are being used differently according to the changed attitude to the world, real objects and current events. All the facts demonstrate different stages of a live language development and these stages resemble development process in nature and society where removability of stable and unstable epochs is a sine qua non condition. Alternation of instability and order in nature and society is not destructive because something new originates from it. Not only development of nature and society but also language development have certain common features and can be described from the same philosophical point of view. This point of view is suggested in the synergy conception.

Philosophical conception of instability or synergy had been presented by I. Prighozin (Prigozhin 1991: 46-52) and was applied to natural science studies at 
the end of the XX century. According to synergy point of view, alternation of instability and order in nature and society is not destructive: something new originates from it (Prigozhin 1991: 49). Development is characterized as a dissipative process which has two results: order and disorder existing at the same time. Dissipative process leads for the originating of highly organized structures (Prighozin 1991: 49). Synergy attempt to the language looks very well-timed and Russian language presents a lot of material for applying it.

At the times of social instability a language reacts immediately: new ways to describe the world and to express one's attitude to it appear. Increasing of personal expressive and evaluating elements in a language not only shows typical human intention to self-expression but reflects variable and contradicting events which form everyday life in the unstable and always changing world. Modern society becomes more and more individualized. All types of hierarchy and traditional connections (professional, regional, private etc.) in it are being destroyed. Individualization comes together with the feeling of uncertainty which leads to the decreasing of security level for a certain individual and also for his social surrounding (Marinov 2008: 7). All these circumstances force a human being to concentrate on the short term goals instead of long term ones which means refusing from stability as an obligatory characteristic of life (Marinov 2008: 89). New live orientation is reflected in the current language. Dependently on the position at the exact moment, a human being receives different sometimes contradicting evaluations and descriptions in this type of society.

At the time of changes colloquial language and the language of contemporary literature display more information about the current period of time than the topics and content of the dialogs and the texts. Rich and detailed picture of this connection is presented in Russian language. The number of language features reflecting unstable historical epochs is great but some of them attract special attention. An interesting phenomenon takes part at the lexical level: the principals used to describe humans and lifeless objects are being changed. A human is being described as a mechanical device or lifeless object meanwhile lifeless objects receive human features. Such examples take place in totally different functional styles of Russian language. An interesting parallel appears at the beginning of the XX century.

Furniture receives some human features in the prosaic works of V.Nabokov. It appears already in his first novel Mashenka (1926): "Чета зеленых кресел тоже разделилась: одно скучало у Ганина, в другом сиживала хозяйка или ее старая такса" (Nabokov 1990:12); ["A pair of green arm-chairs was also severed: one pined in Ganin's room, and the other one was used by the landlady herself or by her old dachshund"(Nabokov 1970:6)]; “Один из двух стульев, вместо того, чтобы стоять у письменного стола [...] забрел было в сторону маленького умывальника, но на полпути остановился, видимо спотыкнувшись об отвернутый край зеленого коврика" (Nabokov 
1990:31); ["...one of the two kitchen chairs seemed to have wandered off in the direction of the washbasin but had stopped halfway there, having obviously stumbled over the turned-up edge of the green carpet" (Nabokov 1970: 27)]. Humanizing of lifeless objects is a deliberate method of description in Nabokov's works. But could not this method appear as a result of the author's perception of an active language tendency? In was noticed that some writers who had deep understanding of the language process were able to anticipate the directions of its development and use in their works the language models which have big future (Paducheva 2009: 557).

Nabokov's novel belongs to the serious literature but approximately at the same time when the novel Mashenka was created the "alternative" descriptions of a human were used in the other functional style of Russian language. This example was found in the speech of a marginal social group which had seldom acted as an object of linguistic studies. Lichatchev published in 1935 the article presenting the ways of humans and lifeless objects description in the speech of criminals. Language material for the article was collected at Solovki prisoner camp where future academician had spent two years from 1928 till 1931. Parts of the human body receive the following names: head - "water melon"; forehead — "attic"; eyes — "wheels", "balls"; throat — "bell", "whistle"; hands — "rake", "hooks"; legs — "reel", "wheels" (Lichatchev 1935:80). According to Lichatchev, "such 'mechanized' man doesn't go but 'rolls', he doesn't speak but 'rings' or 'uncoils', doesn't fell in love but 'fall over' somebody, doesn't think but 'hung'. Pride forces him to 'inflame'. He can be 'filled with oil' or 'shaken out' etc." (Lichatchev 1935: 80). At the same time lifeless objects are described like live creatures: safe - 'bear', 'bear cub'; bullet — 'small bee'; back pack - 'small monkey'; laundry at the attic — 'pigeons'; lock - 'sparrow' (Lichatchev 1935: 80).

Lichatchev evaluates those elements of criminal language as features of primitive thinking which is very close to the mythological one. Conception of the world reflected in the language of criminals "brings it [the world - N.P.] to the simple chain of circumstances, mechanizes it, and takes any initiative and responsibility for actions away from it" (Lichatchev 1935: 80). While a man becomes mechanical the world undergoes an 'animalization' which makes it more predictable and understandable (Lichatchev 1935: 81).

As a result examples of two contradicting tendencies appear in Russian language approximately at the same time: humanization of furniture in the exquisite Nabokov's prose and mechanization of a man in the language of criminals. Both situations bring us to the conclusion that the picture of the world reflected by such different subjects in such functionally and stylistically different texts has certain specificity noted not only by a writer but also by people who stayed very far from literature process. Destruction of laws and norms of human society had been began by the industrial revolution at the boarder of the XIX-XX centuries and continued after the revolution. Language reflection of this social process in prose had the same features that were traced 
in the speech of a marginal asocial group. It looks like the idea that a human described like a lifeless object has no initiative is relevant not only for the marginal group argot but in certain ways shows itself in the literary text reflecting the picture of the world at the unstable period which affects the whole society.

Studies of Russian language during the post-revolutionary epoch mark one common tendency: changes of the state structure brought serious changes in the language such as disappearing of the high style and large lexical groups connected with the abrogated state system, blending of functional styles, intruding of colloquial elements and vernacular language into the everyday speech including criminal argot (Karcevskij 1923, Protchenko 1969, Selishev 2003). Later on a big quantity of criminal argot had entered into the everyday usage accompanied with the disappearing of its original expressive connotations and this process continued at the 90-th of the XX century during the time of state structure changes in the post-Soviet epoch. Thus some elements of marginal groups' language took a chance to approach stylistically higher levels of Russian language (Sklarevskaja 1998).

Modern Russian language is characterized with the wide democratization process which appears at the all levels of the language. Democratization increases its power today and reflects not only in the colloquial speech but also in the modern literature. It includes continuing tendency to mutual exchanging of words in descriptions of humans and lifeless objects. Changes of this type are used as a special method in the modern prosaic texts. Applying of this method provides better understanding of the senses input by the author in the texts. For example, in the novel Germans by A. Terehov (2013) the main hero and his surrounding are clerks, administrative employees whose lives depends on the fads and whims of their bosses. Because of this situation the fact that some of the personages are being described as lifeless objects doesn't surprise.

A fired colleague of the main hero looks like a mechanism: “Звонить Фрицу незачем, его погасили, на Фрице нащупали выключатель и отключили" (Terehov 2013: 163); [lit.: There is no need to call Fritz, they discharged him; they had grouped for the power switch on Fritz and disconnected him] (examples from the novel by Terechov are presented in our translation). A female attorney is presented rather grotesquely: “... из таких получаются лучшие жены, если не передержать их на ветру, тогда мясо становится жестким и мстительным' (Terehov 2013: 163); [lit.: ...the best wives come out of such ones if they are not over stored under the wind or the meat becomes tough and revengeful]. Two meanings of the word жесткий (tuff) make the description uneasy. Two ways of interpretation can be applied to this example: meat (like a lifeless object) is not cooked enough for eating and at the same time (like a live creature) it has strong or tuff character. Later the heroes' impression shows more scary images: “... и он почуял это большое, не по-человечески одетое тело <...> чуял не как тело, а как сложенный, складной инструмент, 
как веер, парашют, уложенную тесно палатку, саблю в чехле, рыбу - не тело, не то, что потеет" (Terehov 2013: 249-250); [lit......and he had scented this big hot humanly dressed body... he scented it not like a body but like a folded flic instrument, like a fan, a parachute, a tightly laid tent, a sable in the case, a fish but not like a body, not like a thing which sweats].

Sometimes people are described through the prism of a personage vision as if they belong to the world of animals: “...монстр [here: a high rank administrative official - N.P.] вразвалку, с дополнительным усилием отрывая ступни, пошел на онемевший, докучдивый, бессмысленный мир животных и насекомых - жители загоготали и затрепали крыльями для ободрения себя..." (Terehov 2013: 257); [lit:...the monster moved towards the silent, annoying, senseless world of animals and insects - the inhabitants began to gaggle and to shake wings to encourage themselves].

The main hero sometimes evaluates people who don't belong to his world like lifeless objects. That is how he describes war veterans protesting against construction works in the park: “Одной рукой подхватил за локоть ответно захрипевшего ветерана и другой рукой за локоть второго (послезавтра эти обломки, этот м⿻х будет в Кремле, а через полгода наконец-то передохнут)" (Terehov 2013:260); [lit.: He took with one hand the elbow of the veteran who wheezed in response and took the elbow of the second one (tomorrow there debris, this moss will be in the Kremlin and in a half of the year they will be finally dead)].

Sometimes human's actions and feelings receive independence and behave like live creatures: “по лицу его самостоятельно, не отвлекаясь на произносимое, переползали разнообразные гримасы в пределах от «мне жарко, сдохну сейчас» до «так вот он, рай»" (Terehov 2013: 233); [lit.:...different grimaces in the frame from "what a heat, I'll dye now" to "oh, that is Paradise" were crawling across his face independently without distracting to the pronounced words].

At the same time objects show rather animalistic features: “...как онемевшие гуси, сбежавшиеся за кормом, - бутылки шампанского тянули серебристые горла, расталкивая обтянутые пленкой бока конфетных коробок" (Terehov 2013: 161); [lit.: ...like geese turned numb and hurried for food champagne bottles stretched their silver necks pushing away tufted with plastic boxes of sweets].

Traditional norms don't work in the world where the heroes of the novel exist. Human being life is unpredictable and chaotic there. Everything is mixed over. Instability becomes the main factor forcing personages to act in the constantly changing conditions. A human being loses its individuality and receives characteristics of mechanism. A "humanized" object takes the place of a human being. Description of human being like lifeless objects and vice versa destroys ordinary logic but it is an effective and productive way to reflect author's perception of the world in the time of changes. This situation provokes 
activation of potential language units' abilities and in many ways inspires creation of new language norms and new methods of changing reality reflection. Language facts which had been noticed as periferic phenomena at the different stylistic points in the twentieth century appeared again in the modern prose as a meaningful method. Contradicting and paradoxical descriptions of the world picture in general and of a human being in particularity join together the feathers of chaos and stability (in lexical and syntactic levels) and with the help of this create Russian prosaic text of the beginning of the twenty-first century. Following the synergy point of view Prigozhin summarized that all human and social interactions and all literal activity were the expression of indefinitivity towards the future (Prighozin 1991: 48). Language units connected with the certain historical epochs which have been analyzed here demonstrate the features of instability and indefinitivity. It brings to the conclusion that the language shows in this case the characteristics of a dissipative structure which is included as an equal component into social and natural processes and it means that the synergy attempt to the language has good perspectives and can bring interesting results.

\section{BIBLIOGRAPHY}

KARCEVSKIJ, S.L. (1923), “Language, war and revolution” [Access: 15 December 2015]. Available at: $<$ http://crecelo.seriot.ch/textes/Karcevskil23.html $>$.

LICHACHEV, D.S. (1935), "The features of pristine primitivism in the thieves speech", in Language and thinking. Le langage et la mentalité, Moscow-Leningrad, USSR Academy of Science, $\mathrm{N}^{\circ}$ III-IV, 47-100.

MARINOV, M.B. (2008), Transformation of personal life strategy in the individualizing society, Moscow, Socialno-gumanitarnyje znanija.

NABOKOV, V. V. (1970), Mary, New York, McGraw Hill (trans. by M. Glenny with the collaboration of the author).

NABOKOV, V. V. (1990), Mashenka, in Nabokov V.V. Collection of works in 4 vol., Moscow, Pravda, Vol.1, 7-164.

PAducheVA, E.V. (2009), "Russian literary language before and after Pushkin", in Paducheva, E.V., Articles of different years, Moscow, Jazyki slavjanskih kultur, 548557.

PRIGOZHIN, I. (1991), "Philosophy of instability", Voprosy filisofii, 6, 46-52.

PROTCHENKO, I.F. (1969), "From the essays on the lexical studies", in Scientific notes of MGPI named after V.I. Lenin Vol.34. Voprosy philologii. Moscow, MGPI, 298-303.

SELISCHEV, A.M. (2003), The language of revolutionary epoch. Observations on the Russian language (1917-1926), Moscow, URSS.

SKLAREVSKAJA, G.N. (1998), "Introduction", in Explanatory dictionary of the end of the XX century. Language changes, Saint-Petersburg, Folio-Press, 7-15.

TERECHOV, A.M. (2013), Germans, Moscow, AST. 